\title{
SISTEM INFORMASI JASA PENGIRIMAN SURAT DAN BARANG PADA PT. POS INDONESIA KOTA TANGERANG
}

\author{
Ruli Supriati ${ }^{1}$ \\ Andri Yanti Irmawan² \\ Gista Melandy ${ }^{3}$ \\ Dosen STMIK Raharja ${ }^{1}$ \\ AMIK Raharja Informatika Jurusan Manajemen Informatika ${ }^{2,3}$ \\ Jl. Jenderal Sudirman No.40, Modernland, Tangerang ${ }^{1,2,3}$ \\ E-mail : ruli@raharja.info ${ }^{1}$, andri.yanti@raharja.info ${ }^{2}$, gista@raharja.info ${ }^{3}$
}

\begin{abstract}
ABSTRAK
Sistem informasi pengiriman surat dan barang pada perusahaan yang bergerak di bidang jasa menjadi sangat penting, sehingga harus diatur dengan baik. Tujuan penelitian yaitu untuk mengetahui bagaimana sistem informasi pengiriman surat dan barang yang sedang berjalan pada PT. Pos Indonesia. Dalam memperoleh data yang diperlukan penulis menggunakan beberapa metode, yaitu metode pengumpulan data dan metode analisis. Metode pengumpulan data dengan melakukan observasi, wawancara serta studi pustaka dari beberapa penelitian sebelumnya, pada metode analisis penulis melakukan analisa sistem menggunakan UML (Unified Modelling Language). Berdasarkan analisa sistem berjalan diperoleh hasil bahwa pada sistem yang ada saat ini dapat membantu pegawai dalam menginput data kiriman dan penerimaan kantong. Maka dapat disimpulkan bahwa dengan adanya sistem IPOS pada perusahaan, akan membuat proses pengiriman surat dan barang menjadi lebih akurat, cepat serta tepat waktu sehingga bisa lebih efektif dan efisien.
\end{abstract}

Kata Kunci : Sistem pengiriman, surat, UML (Unified Modelling Language)

\begin{abstract}
Delivery of mail and goods that take a long time because they use two systems in one computer to make the customer disappointed with the lack of timely delivery. Therefore, information systems and mail delivery of goods to companies engaged in the service to be very important, so it should be well regulated. The purpose of research is to find out how the system of mail delivery information and items that are running on PT. Pos Indonesia. In obtaining the necessary data the author uses several methods, the method of data collection and analysis methods. Data were collected by observation,interviews and literature study of some previous studies, the author analysis methods to analyze the system using UML(Unified Modelling Language). Based on the analysis result that the system is running on the system that exists today there are still some shortcomings, therefore it is necessary to reform the system more quickly and accurately.Then, it can be concluded that by applying system updates on the company, will make the process of sending letters and goods become more accurate,quick and timely so that it can more effectively and efficiently.
\end{abstract}

Keywords: System delivery, mail, UML (Unified Modeling Language) 


\section{PENDAHULUAN}

PT. POS Indonesia (Persero) merupakan sebuah Badan Usaha Milik Negara (BUMN) Indonesia yang bergerak dalam bidang jasa pengiriman surat dan barang. Yang mempunyai berbagai tugas salah satunya yaitu untuk melaksanakan dan menunjang kebijakan program pemerintah dalam bidang ekonomi juga pembangunan, pada umumnya memberikan pelayanan jasa pengiriman bagi seluruh masyarakat di Indonesia maupun diluar wilayah Indonesia. Tujuan dari dibentuknya perusahaan ini adalah memberikan pelayanan jasa pada masyarakat dalam hal mempercepat pengiriman didalam negeri maupun diluar negeri. Pengiriman yang cepat dan tepat waktu adalah tujuan utama PT. Pos Indonesia dalam memberikan pelayanan yang baik kepada masyarakat, Tujuan kirim bisa ketujuan kantor pos cabang dan bisa dikirim keluar daerah. Daerah cakupan kiriman tidak hanya menjangkau satu wilayah atau satu negara, tetapi PT. POS Indonesia (persero) juga melayani kiriman ke berbagai Negara.

Perkembangan suatu ilmu pengetahuan di era globalisasi saat ini begitu pesat, terutama dalam bidang teknologi, begitu juga dengan kebutuhan terhadap jasa pengiriman barang semakin tinggi. Akan tetapi, dengan meningkatnya kebutuhan konsumen atas pelayanan jasa pengiriman barang, maka semakin banyak pula jasa pengiriman bisnis swasta seperti JNE, TIKI dan juga JTN Express yang bisa menyebabkan menurunnya rasa kepercayaan masyarakat terhadap PT. POS Indonesia (persero). Oleh karena itu PT. Pos Indonesia melakukan pembenahan dalam sistem pengiriman dokumen dan jasa agar dapat bersaing dengan kompetiter jasa pengiriman swasta yang lain. Oleh karena itu dengan melakukan pembenahan pada sistem pengiriman tersebut, PT. Pos Indonesia menggunakan sistem komputer atau bisa dikatakan sudah terkomputerisasi dengan baik dalam mencetak data dan mengirim data. Sistem yang digunakan ini dapat membantu PT Pos Indonesia dalam bersaing dengan jasa pengiriman swasta lainnya. Sistem computer yang digunakan saat ini adalah IPos dengan pembuatan sistemnya menggunakan Visual Basic. Menggunakan sistem computer ini dapat mempermudah pekerja atau pegawai dalam membuat sebuah laporan.

\section{RUMUSAN MASALAH}

Berdasarkan latar belakang diatas, maka perumusan masalah penelitian ini adalah :

1. Bagaimana sistem informasi pengiriman barang dan surat yang sedang berjalan pada PT. Pos Indonesia kota Tangerang?

2. Tools apa saja yang terdapat pada sistem informasi pengiriman barang dan surat pada PT. Pos Indonesia kota Tangerang ?

3. Metode apa yang digunakan dalam menganalisa sistem informasi pengiman barang dan surat pada PT. Pos Indonesia kota Tangerang ? 


\section{LANDASAN TEORI}

\section{Definisi Jasa Pengiriman Barang}

Menurut Suyono yang dikutip dalam penelitian Nuferin 2014, Jasa pengiriman barang adalah usaha dengan tujuan untuk memberikan jasa pelayanan atau pengurusan atas segala kegiatan yang diperlukan bagi terlaksananya suatu pengiriman, pengangkutan serta penerimaan barang dengan menggunakan multimodal transport baik itu melaui darat, udara ataupun laut.

Menurut PER-178/PJ/2006 yang dikutip dalam penelitian Nuraeni Sri Wulandari 2015, Jasa pengiriman barang adalah usaha yang dimaksudkan untuk mewakili kepentingan pemilik barang, untuk menangani segala kegiatan yang diperlukan bagi terlaksananya pengiriman dan penerimaan barang melalui transportasi darat, udara ataupun laut yang bisa mencakup kegiatan penerimaan, penyimpanan, sortasi, pengepakan, penandaan pengukuran, penimbangan, pengurusan penyelesaian dokumen, penerbitan dokumen angkutan, klaim asuransi atas pengiriman barang dan penyelesaian tagihan serta biaya - biaya lain yang berhubungan dengan penngiriman barang barang tersebut sampai dengan diterimanya barang oleh yang berhak menerimanya.

Dari beberapa teori - teori tersebut maka dapat disimpulkan bahwa jasa pengiriman barang merupakan suatu usaha yang dimaksudkan untuk membantu segala kegiatan yang diperlukan untuk tercapainya pengiriman serta penerimaan barang melalui transportasi baik itu darat, udara ataupun laut.

\section{Definisi Surat}

Menurut Muhammad Luqman, 2012 yang dikutip dalam jurnal Yunita Purnama Sari dan Sukadi Surat adalah media komunikasi tertulis yang digunakan untuk menyampaikan suatu informasi, pernyataan atau pesan kepada pihak lain yang memiliki keperluan kegiatan dengan bentuk tertentu.

Menurut Lamuddin yang dikutip dalam penelitian Nurwendah, 2014 Surat adalah media yang digunakan untuk menyampaikan suatu maksud secara tertulis, bila dilihat dari segi pemakaiannya bisa dikelompokan menjadi 4 macam yakni surat dinas, surat niaga, surat social dan surat pribadi.

Berdasarkan teori - teori diatas dapat disimpulkan bahwa surat merupakan suatu bentuk komunikasi yang tertulis yang digunakan untuk menyampaikan suatu maksud.

\section{LITERATURE REVIEW}

1. Penelitian yang dilakukan oleh Stefani Margaretta, Sri Yulianto J.P dan Martin Styawan pada tahun 2012 dengan judul "Sistem Infomasi Tracking Pengiriman Barang Pada Online Shopping Berbasis SMS Gateway pada PT. Karunia Inti Jaya Agrisarana" Penelitian ini membahas tentang tracking pengiriman barang menggunakan aplikasi shopping chart sebagai media transaksi dan teknologi SMS gatewat. SMS Gateway yang dibangun dapat dimanfaatkan untuk mengirimkan nomor nota transfer, status pengepakan barang dan juga status pengiriman barang.

2. Penelitian yang dilakukan oleh Harry Dhika, Lukman dan Aswin Fitriyansyah pada tahun 2016 dengan judul "Perancangan Sistem Informasi Jasa Pengiriman Barang Berbasis Web" penelitian ini membahas tentang pengiriman barang berbasis web 
yang dibuat dengan metode DFD (Digram Aliran Data), aplikasi ini memuat berbagai informasi pengiriman terkini, memuat informasi tarif, memuat profile dan memberikan informasi lain yang berguna bagi pelanggan.

3. Penelitian yang dilakukan oleh Aries Pratiarso, M. Zen, Samsono Hadi, Mike Yuliana dan Neni Wahyuningdiah pada tahuun 2010 dengan judul "Perbandingan Metode Ant Colony Optimization dan Dijkstra untuk Pengembangan Sistem Pengiriman Barang di Kantor Pos Area Surabaya Timur Berbasis J2ME" penelitian ini membahas tentang perbandingan metode ACO dan Dijkstra, dimana metode ACO ini menentukan rute terpendek sehingga memudahkan petugas dalam mendistribusikan paket - paketnya dan juga lebih efisien dalam segi waktu juga biaya, yang dibandingkan dengan algoritma Dijkstra untuk mengetahui kerja terbaik dari kedua algoritma tersebut. J2ME (Java 2 Micro Edition) diaplikasikan dalam handphone untuk memudahkan user (pegawai pengirim paket pos) dalam mengakses informasi yang telah diolah oleh algoritma ACO.

4. Penelitian yang telah dilakukan oleh Nur Dwi Satika dari Sekolah Tinggi Teknologi Indonesia Tanjungpinang yang berjudul "Sistem Informasi Pengiriman Barang Berbasis Web dengan Metode Transshipment" pada tahun 2014. Penelitian ini mengenai sistem informasi pengiriman barang berbasis web yaitu mencetak code number atau resi yang tujuan untuk mempermudah pekerjaan sehingga dapat meningkatkan kecepatan dalam bekerja.

5. Penelitian yang telah dilakukan oleh Muhammad Thamrin Basri dan Azis Abdillah tahun 2010 dengan judul "Sistem Informasi Jasa Pengiriman Barang PT. Makmur Indah Prasindo" penelitian ini mengenai sistem pengiriman barang mengguanakan metodelogi tinjauan sistem, perancangan sistem informasi distribusi dan juga menggunakan data flow digram (DFD).

\section{PEMBAHASAN}

I Pos adalah sistem computer yang digunakan oleh PT Pos Indonesia Kota Tangerang. Banyak tools yang terdapat dalam aplikasi I Pos ini dalam mempermudah pekerja atau karyawan untuk mencetak data dan mengirim data :

1. Beranda atau tampilan awal

Tampilan ini digunakan untuk memperlihatkan sistem I Pos yang digunakan.

2. Tools penerimaan kantong

Merupakan tools yang menampilkan informasi tentang kantong yang diterima dan kantong yang dikeluarkan

3. Tools manifest kiriman

Merupakan tools yang menampilkan informasi setiap kiriman yang masuk dan kiriman yang keluar. Informasi ini sangat penting untuk pelanggan dalam melacak kiriman yang disediakan oleh PT Pos Indonesia

4. Tools cetak laporan

Menampilkan hasil laporan yang sudah selesai kemudian melakukan pencetakan guna dijadikan arsip bagi pengirim dan dijadikan laporan bagi penerima.

Alur proses yang digunakan pegawai dalam menjalankan sistem IPos ini digambarkan dengan UML (Unified Modelling Language) : 


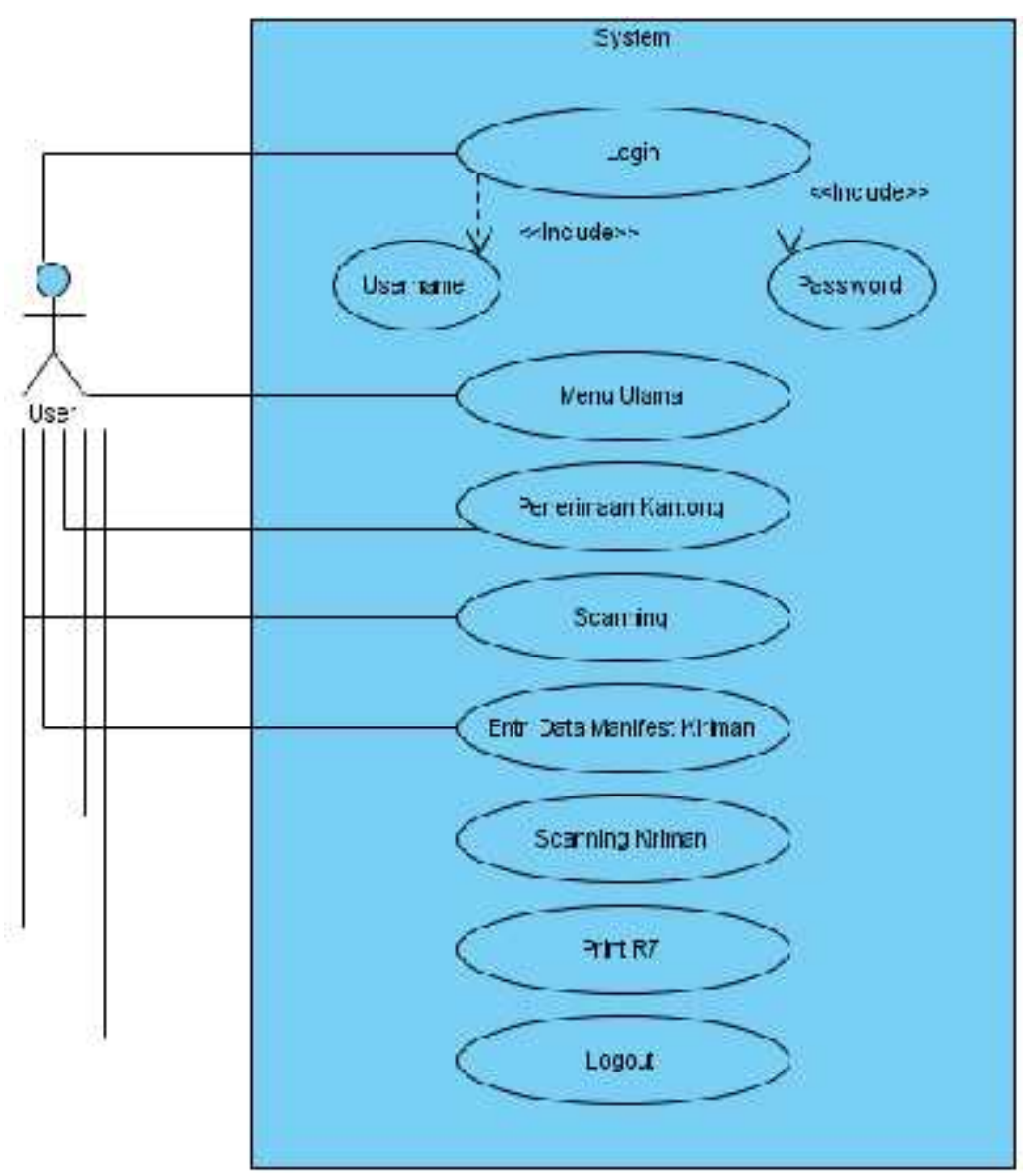

Gambar 1 : Use Case Diagram PT Pos Indonesia

Berdasarkan gambar Use Case Diagram di atas terdapat :

a. 1 sistem mencakup seluruh kegiatan yang sedang berjalan.

b. 1 actor yang melakukan kegiatan, yaitu user (petugas kantor pos).

c. 8 use case yang biasa dilakukan oleh actor.

\section{IMPLEMENTASI}

Tampilan sistem computer Pos yang memiliki berbagai fitur yang digunakan untuk mencetak data dan mengirim data : 
1. Tampilan login

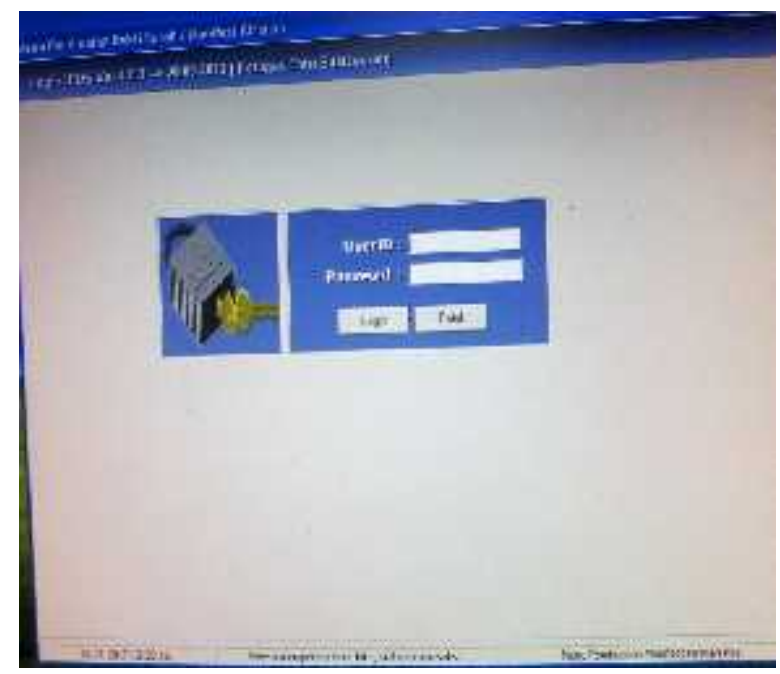

Gambar 2. Tampilan Login IPOS

Tampilan login ini digunakan untuk memasuki sistem I Pos dan sebagai langkah pertama dalam memulai sistem, jika kita membuka sistem maka akan ditampilkan tampilan login tersebut sehingga orang yang tidak bertanggung jawab tidak akan bisa masuk ke dalam sistem tersebut.

2. Tampilan menu

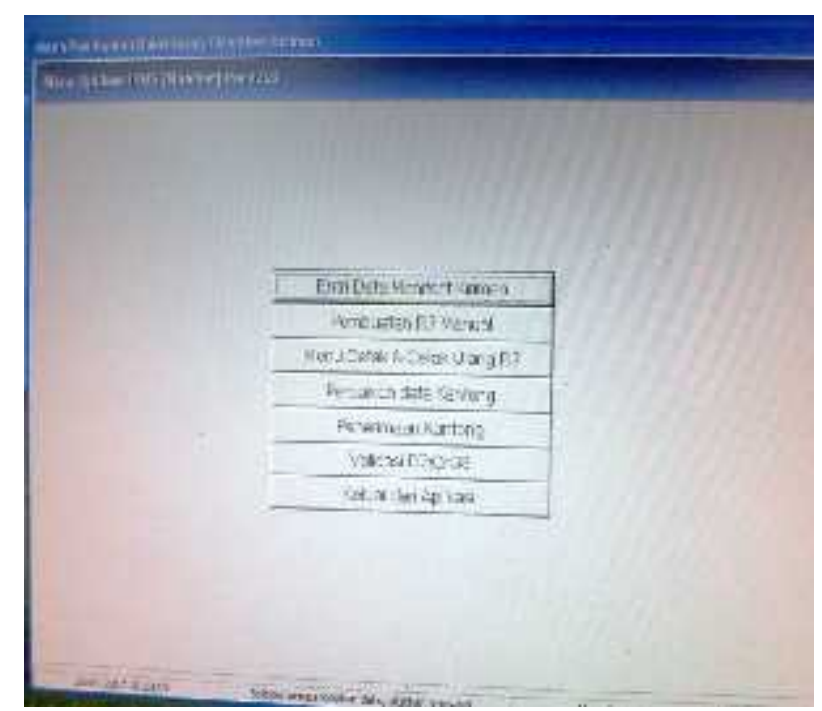

\section{Gambar 3. Tampilan Menu Aplikasi IPOS}

Digunakan oleh pegawai atau karyawan dalam memulai proses pendataan, yang terdiri dari scan kantong, scan kiriman, pembuatan laporan dan terakhir pencetakan laporan. 
3. Tampilan penerimaan kantong

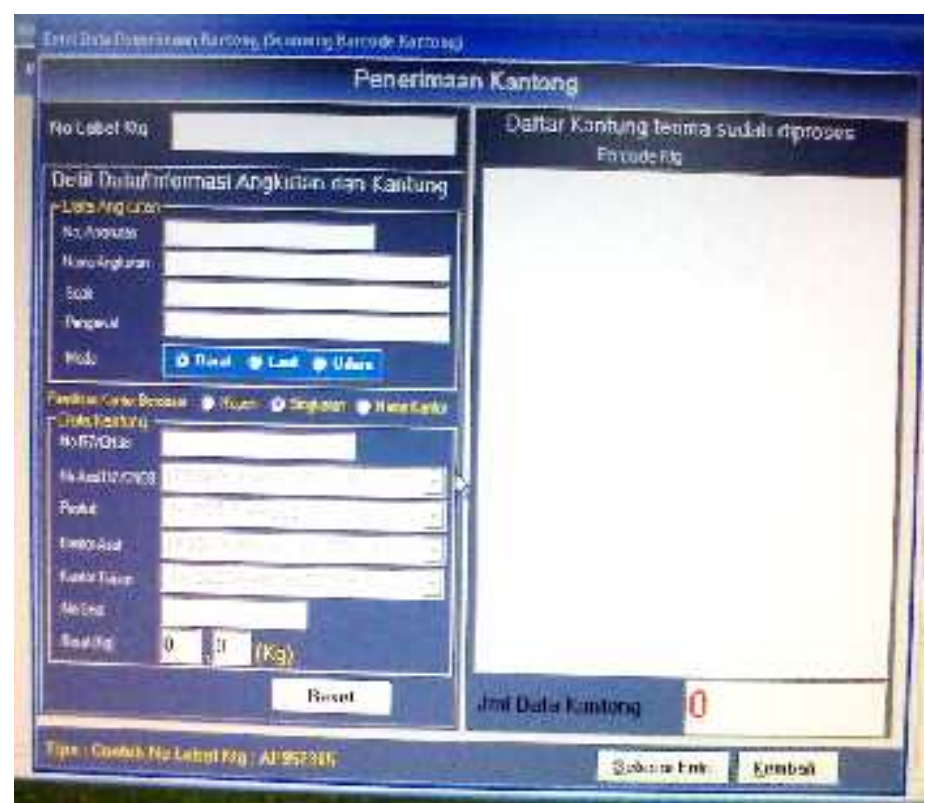

Gambar 4. Tampilan Penerimaan kantong

Digunakan untuk mendata kantong yang masuk dan kantong yang keluar.

4. Tampilan manifest kiriman

a. Puri Kirim

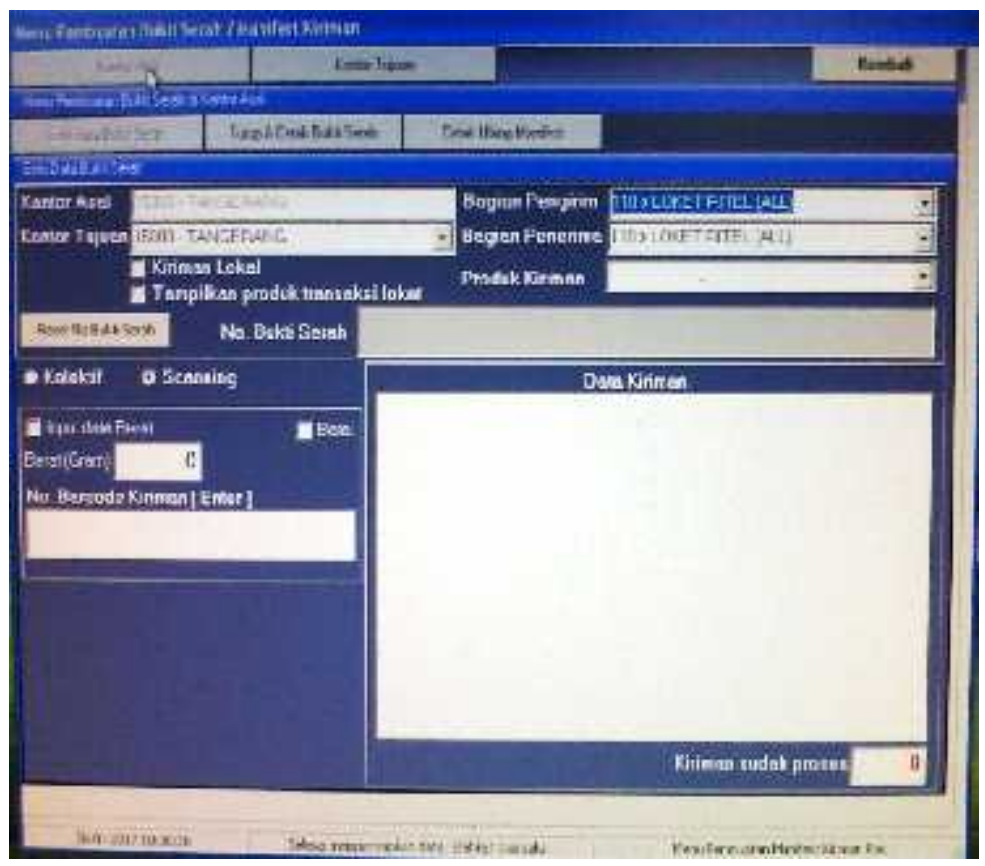

Gambar 5. Tampilan Menu Pembuatan Bukti Serah 
a. Puri Terima

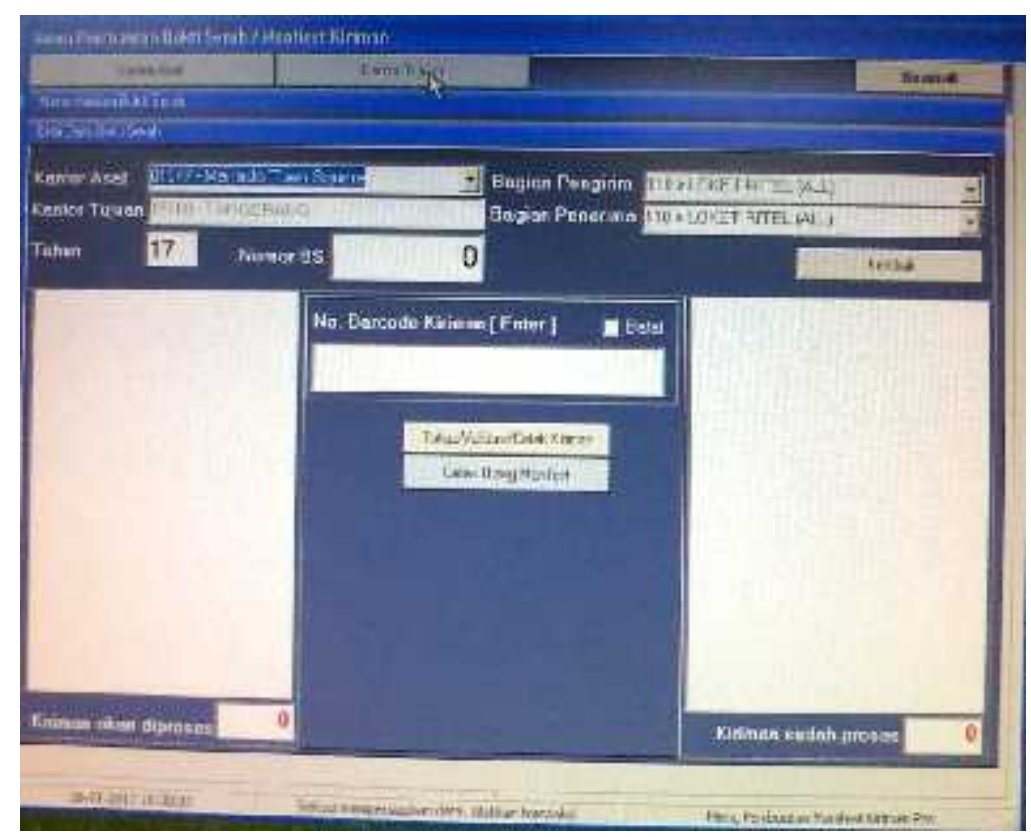

\section{Gambar 6. Tampilan Menu Pembuatan Bukti Serah}

Digunakan untuk mendata setiap kiriman yang masuk dan kiriman yang akan keluar.

5. Tampilan cetak laporan

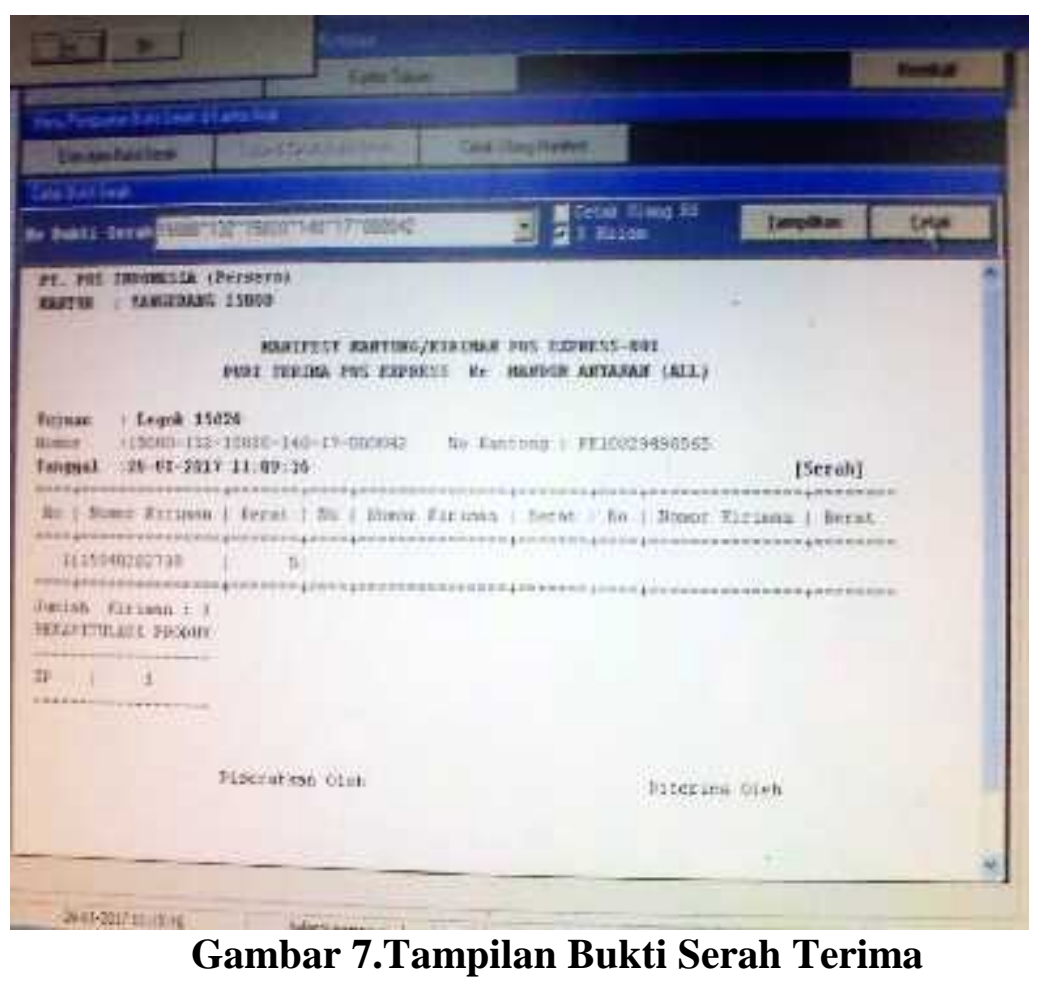


Laporan yang telah dibuat akan dicetak yang kemudian akan dijadikan laporan bagi penerima dan akan dijadikan arsip bagi pengirim.

\section{KELEBIHAN}

Kelebihan dari sistem IPos adalah :

1. Membantu pegawai atau karyawan dalam menginput data keluar dan masuk.

2. Menghemat penggunaan kertas.

3. Kesalahan yang ditimbulkan tidak terlalu sering.

4. Laporan yang dihasilkan terlihat rapih.

5. Data yang dibutuhkan dapat dicari dengan cepat.

\section{KEKURANGAN}

Kekurangan pada sistem I-Pos adalah sistem dibuat menggunakan Visual Basic sehingga sistem yang dihasilkan pun terlihat rumit dan terlalu banyak tools-tools yang ditampilkan.

\section{KESIMPULAN}

Sistem informasi pengiriman surat dan barang pada PT. Pos Indonesia kota Tangerang sudah terkomputerisasi dengan baik, terbukti dengan adanya sebuah sistem aplikasi IPOS yang sangat membantu pegawai dalam penginputan data kiriman dan penerimaan kantong. Sistem ini juga bermanfat dalam mengurangi pemakaian kertas sehingga dalam pencatatan dan penghitungan dapat dilakukan secara cepat dan mudah dan menjadi lebih efektif serta efisien.

\section{DAFTAR PUSTAKA}

[1] Nuferin. 2014. "Sistem Informasi Electronic Customer Relationship Management (E-CRM) di PT. Bintang Jasa Gemilang". http://widuri.raharja.info/index.php/SI1111465600\#Konsep_Dasar_Jasa_Pengirima n_Barang. 19 Maret 2017.

[2] Wulandari, Sri 2015. "Analisa Sistem Informasi Jasa Pengiriman Barang Pada CV. Wikita".https://widuri.raharja.info/index.php/KP1411477628\#Jasa_Pengiriman_Bar ang. 19 Maret 2017.

[3] Sari,Yunita Purnama. 2013. "Siste Informasi Persuratan Pada Dinas Pendidikan Kabupaten Pacitan Berbasis Wen". IJNS-Indonesian Journal on Networking and Security ISSN 2302-5700.

http://download.portalgaruda.org/article.php?article=81183\&val=4926. 19 Maret 2017.

[4] Nurwendah. 2014. "Perancangan Sistem Informasi Pelacakan Surat Masuk dan Surat Keluar Berbasis Web Pada Kecamatan Curug Kabupaten Tangerang". https://widuri.raharja.info/index.php/SI1111469246\#Konsep_dasar_pelacakan_surat _masuk_dan_surat_keluar.19 Maret 2017 